\section{More open government - but nuclear testing on the cards $\ell_{100}$}

THE year ahead will be full of extra tasks for Soviet science, with the 70th anniversary of the Revolution likely to be an extra stimulus. The 'Complex Programme for the Integration of Research and Development' in the Comecon countries by the year 2000, announced at the end of 1985 , continues. So will the tasks of implementing the Gorbachev policies of 'openness', the pruning of the academic establishment of eminent but elderly people, the reform of higher education (to make it more relevant to employment) and the elimination of bureaucratic barriers in research and development. Scientists have been told to strive not only to implement the 'scientific/technical revolution' but also to ensure a climate of peace and detente in which such progress could be achieved.

For the Soviet Union 1986 was a mixed year. The problem of the "elimination of the consequences' of the Chernobyl disaster will spill over into the year ahead. But last year's grain harvest, announced as 210 million tonnes, was gratifyingly high though not yet enough for self-sufficiency.

As elsewhere, acquired immune deficiency syndrome (AIDS) will be a problem during 1987. Although only isolated cases have so far been reported within Comecon, the disease can no longer be dismised simply as a scourge of capitalism or the result of a US bacteriological warfare experiment gone tragically wrong.

Mr Gorbachev's avowed policy of openness has meant that setbacks and highlevel disagreements have become public knowledge, both at home and abroad. Within the bloc, only Romania seems to stand out against the new fashion. One unexpected consequence is more frequent press reports of science-related crimes.

From the Soviet point of view, the main issue for 1987 is undoubtedly arms control, where scientists are involved in two principal ways: in opposition to President Reagan's Strategic Defense Initiative (SDI) and in support of a moratorium on nuclear tests. There has been little movement on either issue, but the Soviet media have kept up an indefatigable campaign, often involving scientists.

At the same time, while insisting that they do not intend to militarize space, Soviet scientists say they are working on 'asymmetric measures' to counter proposed US nuclear-pumped X-ray lasers. These measures (said to cost less than 5 per cent of SDI), are outlined in a recent book, Space Weapons - A Security Dilemma, by a team whose members all belong to the Committee of Soviet Scientists in Defence of the Nuclear Threat. Their method of 'weakening' the SDI umbrella includes the use of missiles, space mines, shrapnel and ground-based lasers.

Meanwhile, the nuclear-test moratorium has lapsed, in the absence of an acceptable US response, as Soviet participants at the Pugwash meeting in Budapest in September had warned it might. But although the Pugwash participants said that, without a US response, Gorbachev would not be able to resist the pressure from his military hawks to resume testing, Academician Evgenii Velikhov, a leading nuclear physicist and arms control negotiator (who missed the Pugwash meeting because of illness), said in an interview on Radio Bremen in November that there is no such 'hawkish' pressure.

At home, one major decision of the past year was the cancellation of the 'project of the century', the proposed diversion south of the northward-flowing rivers of Siberia and northern Russia, supposedly on the advice of technical experts. But the writer and historian Dmitrii Ligachev, who led a campaign against the scheme, now claims its abandonment as a triumph for the "representatives of culture, the writers

and intelligentsia". Doubts have already attached to other major hydroengineering schemes, notably the proposed DanubeDnieper canal and the plan to transfer water from western to eastern Georgia.

In spite of this year's good grain harvest - in a year of exceptional drought - agriculture will preoccupy the planners in the year ahead. Four years after the inauguration of the grandiose 'food programme', the last major political decision of the Brezhnev era, it is tacitly accepted that the plan in is present form is unlikely to succeed. Not surprisingly, Soviet agriculturalists are seeking new solutions. Biotechnology is one answer. During Gorbachev's visit to Hungary last summer, he expressed particular interest in Hungarian achievements in this field, and selected Soviet students have been enrolled at the agricultural university of Godollo, near Budapest, which offers undergraduate courses in biotechnology.

Another solution is to encourage new foms of agricultural production. Although the new Soviet enabling legislation permitting a limited measure of private enterprise does not formally extend to agriculture (apart from small 'household plots'), some limited experiments on the Chinese model have been reported in favourable terms in the Soviet media.

\section{Prospects for 1987 Soviet Union Vera Rich in London}

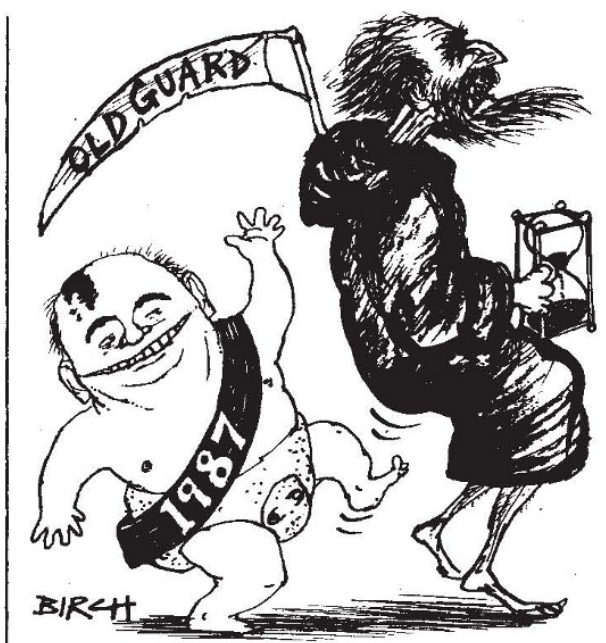

These developments contrast with the situation elsewhere in the bloc. In spite of opposition from Charter-77 in Czechoslovakia and the political 'blues' and the apolitical Danube Circle in Hungary, construction of the Gabcikovo-Nagymaros hydroelectric scheme goes ahead. In Poland, after more than four years of bureaucratic wrangling, the Roman Catholic Church has had to abandon its scheme to channel Western funds into the small private farms that account for some 75 per cent of all agricultural land.

Gorbachev's other major reforms are making slow progress. The scientific/ industrial complexes so far established have failed to overcome the bureaucratic barriers between research and production, except for those such as the Paton Institute of Electric Welding of the Ukranian Academy of Sciences which already flourished before the reform. The Soviet Academy of Sciences has a new chairman, and some leading figures in the academies of the union republics have been pensioned off, but there is still an air of gerontocracy in the academy.

The main Soviet achievement of the past year, perhaps, has been to turn the Chernobyl tragedy into a demonstration (at least after the first few days) of the new policy of openness. Soviet experts at the Vienna accident review conference more than redeemed their country's reputation. Soviet support of the Rapid Notification and Mutual Assistance conventions, and the announcement soon afterwards of an accident to a nuclear-powered submarine, substantiated Soviet assertions that the post-accident delays after Chernobyl would not occur again.

This openness, together with some Soviet relaxation on human and civil rights and the release of political prisoners in Poland, as well as partial withdrawal of troops from Afghanistan in November, have all made breaches in the barriers to the resumption of East/West scientific contacts and exchanges broken off or allowed to lapse during the political frost of the early 1980 s. 